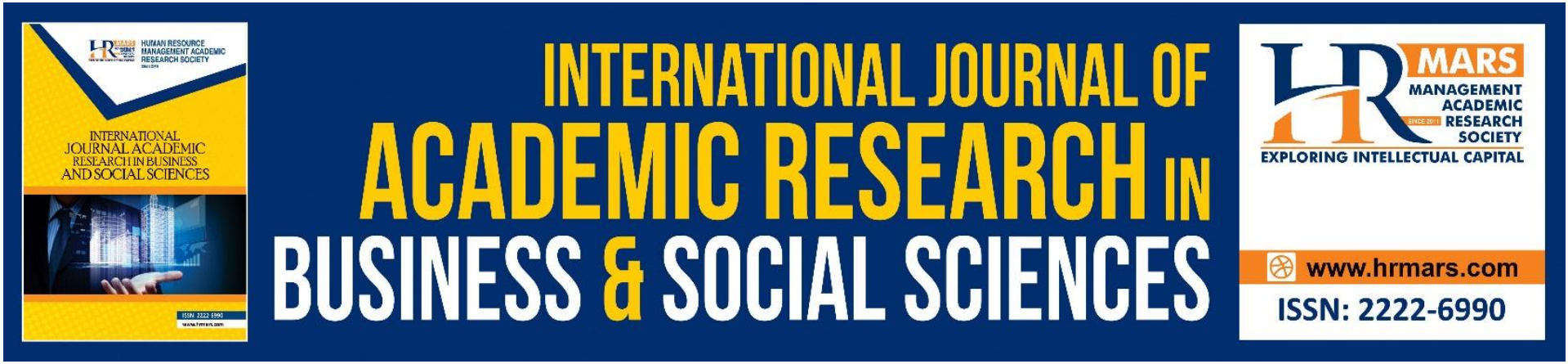

\title{
How to Curb the HIV/AIDS Prevalence in Bangladesh?
}

\author{
Hira F. A., Harcharanjit Singh, Moshiul A. M., A. S. Shahriar
}

To Link this Article: http://dx.doi.org/10.6007/IJARBSS/v11-i5/9800

DOI:10.6007/IJARBSS/v11-i5/9800

Received: 13 March 2021, Revised: 20 April 2021, Accepted: 02 May 2021

Published Online: 16 May 2021

In-Text Citation: (Hira et al., 2021)

To Cite this Article: Hira, F. A., Singh, H., Moshiul, A. M., \& Shahriar, A. S. (2021). How to Curb the HIV/AIDS Prevalence in Bangladesh. International Journal of Academic Research in Business and Social Sciences, 11(5), 300-309.

Copyright: (c) 2021 The Author(s)

Published by Human Resource Management Academic Research Society (www.hrmars.com)

This article is published under the Creative Commons Attribution (CC BY 4.0) license. Anyone may reproduce, distribute, translate and create derivative works of this article (for both commercial and non-commercial purposes), subject to full attribution to the original publication and authors. The full terms of this license may be seen

at: http://creativecommons.org/licences/by/4.0/legalcode

Vol. 11, No. 5, 2021, Pg. 300 - 309

http://hrmars.com/index.php/pages/detail/IJARBSS

JOURNAL HOMEPAGE

Full Terms \& Conditions of access and use can be found at http://hrmars.com/index.php/pages/detail/publication-ethics 


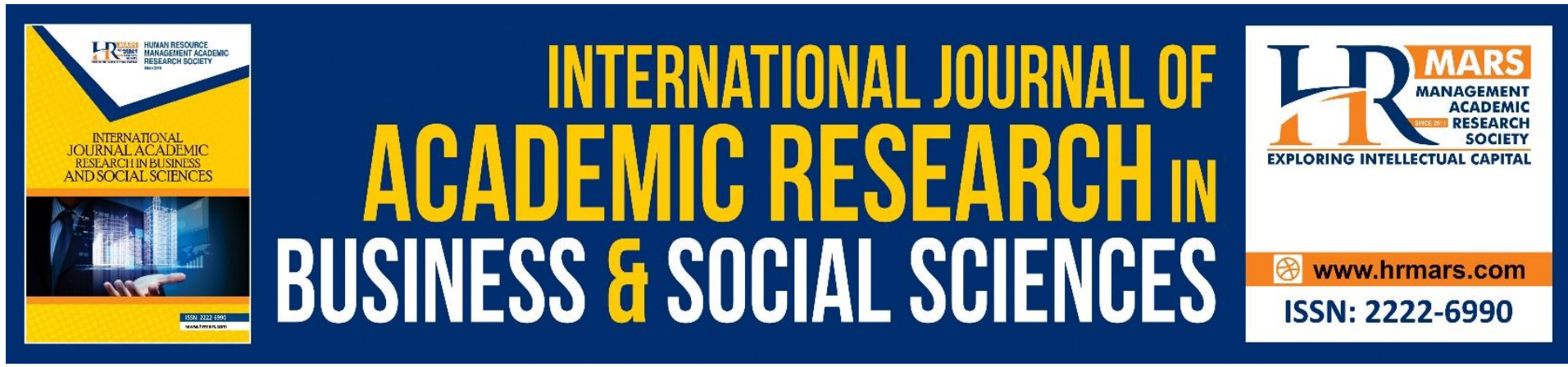

\title{
How to Curb the HIV/AIDS Prevalence in Bangladesh?
}

\author{
Hira F. A. ${ }^{1}$, Harcharanjit Singh ${ }^{2}$, Moshiul A. M. ${ }^{3}$, A. S. Shahriar ${ }^{4}$ \\ ${ }_{1,2}^{2}$ Azman Hashim International Business School, University Teknologi Malaysia, Kuala \\ Lumpur, Malaysia, ${ }^{3}$ Razak School of Engineering \& Advanced Technology, University \\ Teknologi Malaysia, Kuala Lumpur, Malaysia, JJahurul Islam Medical College \& hospital, \\ Bajitpur, Kishoreganj, Bangladesh
}

\begin{abstract}
HIV/AIDS epidemic represents an emerging health threat for the whole World. HIV/AIDS occurrence rate In Bangladesh is still below 1percent but eventually is becoming a threat for the nation. However, the absence of sufficient research on HIV in the Bangladesh context motivates this secondary research. The present study discusses the strength, weaknesses, and interventions taken to combat HIV in Bangladesh. Also, it presents the key challenges that can potentially hinder progress in combating HIV. Finding demonstrates that the massive treatment gap is the core concern coupled with a crucial population such as injecting drug users (IDU), transgender is making the situation even worst. In addition, the Rohingya crisis is causing a sharp surge in HIV/Infection. This research aims to provide policymakers with information and suggestions based on existing studies and HIV/AIDS prevention planning.
\end{abstract} Keywords: Bangladesh, Hijra, HIV, Multi-Sector Approach, Policy Development, Rohingya

\section{Introduction}

Acquired immunodeficiency syndrome (AIDS) is a transmittable ailment caused by the human immunodeficiency virus (HIV). HIV destroys the human immune system and develops AIDS, which results in loss of life. The global occurrence of HIV is about 37 million in which, around 2 million are newly infected in 2017. The massive killer AIDS-associated diseases ended 940,000 lifestyles in 2017, and globally, 21.7 million patients were getting access to antiretroviral therapy. The total number of HIV infections has been declined in the Asia-Pacific region by $31 \%$ for the last 14 years (Koirala, 2017). AIDS-related fatality also has fallen in the ASIA Pacific region; in 2016, AIDS-related death was recorded 170,000; however, the fatality rate dropped by 70,000 compared to the year 2010. UNAIDS (2018) report says that PLHIV in Asia and the pacific is 5.2 million, where 2.8 million patients have access to ART (antiretroviral therapy). Despite that, 1.7 mullions AIDS-related death occurred in this region (Avert, 2018). 
INTERNATIONAL JOURNAL OF ACADEMIC RESEARCH IN BUSINESS AND SOCIAL SCIENCES Vol. 11, No. 5, 2021, E-ISSN: 2222-6990 @ 2021 HRMARS

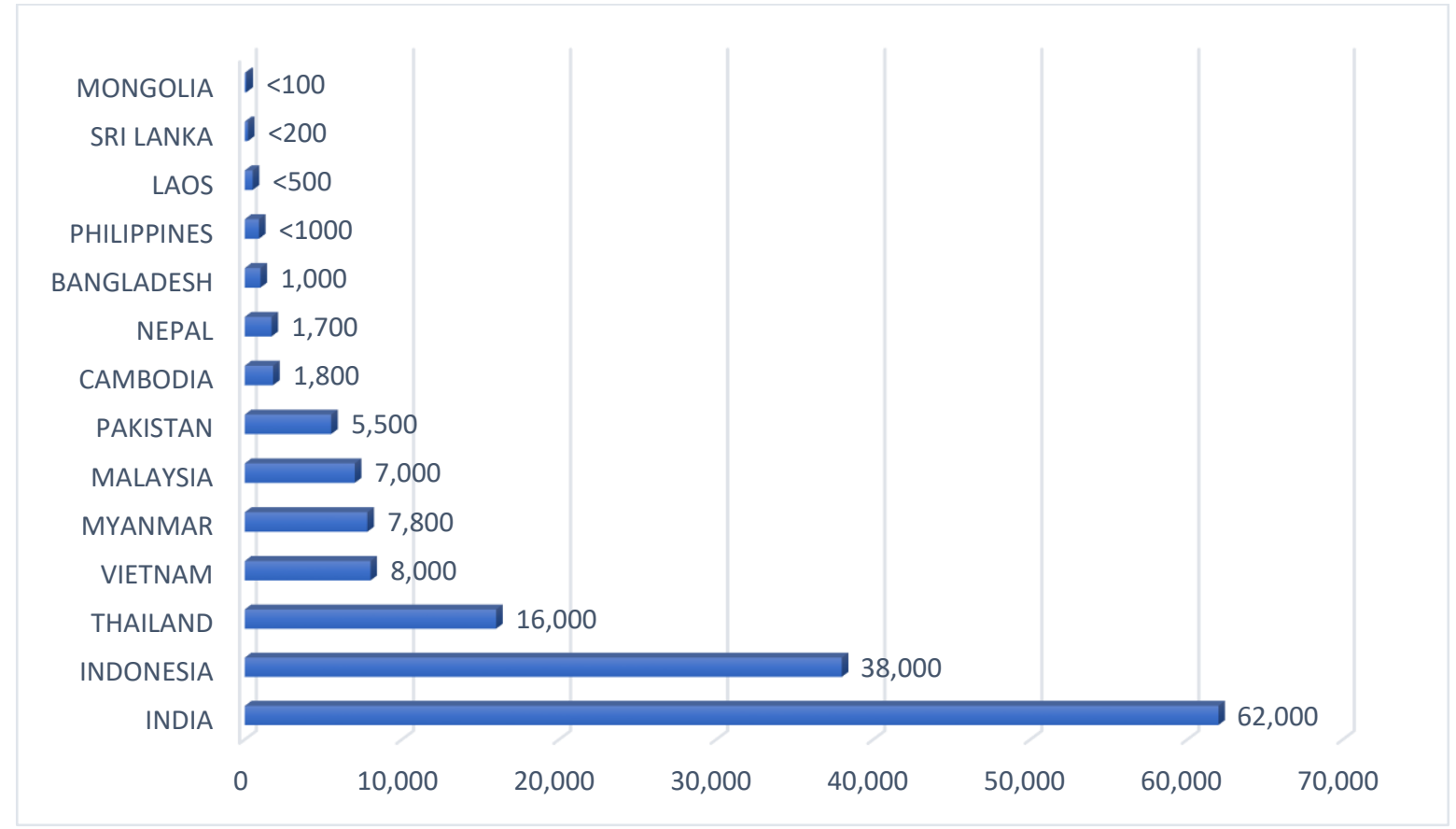

Figure 1: Number of death in Asia due to HIV (UNAIDS, 2017)

Bangladesh is considered a low incidence country (0.1\%), still in inclined condition to an HIV epidemic (Das, 2017). Nevertheless, the first patient detected with the HIV epidemic was in 1989. Since then, the number of HIV patients started increasing. In addition, there are around 1495 HIV/AIDS incidents that have been recorded in Bangladesh (UNAIDS, 2008). Moreover, in 2015 number of HIV patients was 4,143, which was three (3) times higher than the year 2008. Despite that fact, in 2017, 1700 new HIV contamination and 1,100 deaths were recorded in Bangladesh due to AIDS. ART coverage in the country is less than 20\% (Das, 2017), as shown in bellow Figure 1. PLHIV is 13,000, where only 2,470 patients are on ART.

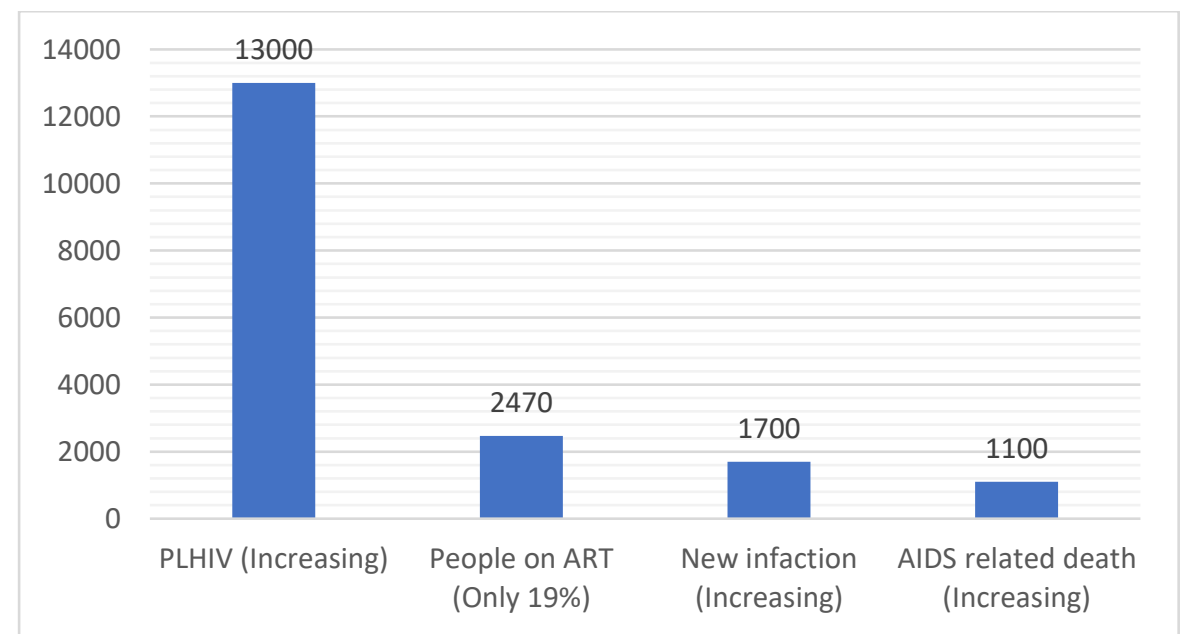

Figure 2: Current Condition of HIV/AIDS prevalence in Bangladesh (Rezwan et al., 2016) 


\section{INTERNATIONAL JOURNAL OF ACADEMIC RESEARCH IN BUSINESS AND SOCIAL SCIENCES}

Vol. 11, No. 5, 2021, E-ISSN: 2222-6990 @ 2021 HRMARS

A government published on global AIDS day mentioned that 869 new HIV patients were identified in 2018. According to Mondal et al. (2012), some scholars predict that the HIV prevalence in Bangladesh could increase as high as $8 \%$ by 2025 among the adult population (ICDDRB, 2017). Hence, this unexpected growth is a matter of apprehension, as HIV has a tremendous effect on humans and the country's overall economic progress (Mondal et al., 2012). Therefore, policy development and reform are mandatory. Thus, the present study highlights the aspects that need to be in focal point while developing policy and deciding to curb HIV/AIDS occurrences. There is a lack of HIV epidemic research in Bangladesh, and little efforts have been given toward key populations (i.e., transgender people, drug users) who are more vulnerable to HIV. Hence, this study aims to increase the current body of knowledge in this particular phenomenon. This question includes; (a) what are the initiatives already taken? (b) what are the weaknesses that are hindering the progress? (c) what approach should be considered to combat HIV/AIDS occurrence? The article, therefore, presents an overview of intervention, shortcomings of the healthcare service delivery and suggests a possible approach in the discussion section. The present study concludes with a research limitation and future research direction.

\section{Data Searching Strategy}

Scholarly database, namely Scopus, T \& F, IEE, Springer link search, resulted in 259 articles which were further screened in few phases. Firs stage of screening was to check for relevance with the research interest. Subsequently, the title, keyword, full texts were screened. Finally, only 46 articles were retained for further analysis, as illustrated in Figure 1 . The keywords used for searching relevant literature include HIV, Bangladesh, Developing country, AIDS, Rohingya. Significant studies on HIV in the Bangladesh context that have been reviewed are mentioned in Table 1. 
INTERNATIONAL JOURNAL OF ACADEMIC RESEARCH IN BUSINESS AND SOCIAL SCIENCES Vol. 11, No. 5, 2021, E-ISSN: 2222-6990 @ 2021 HRMARS

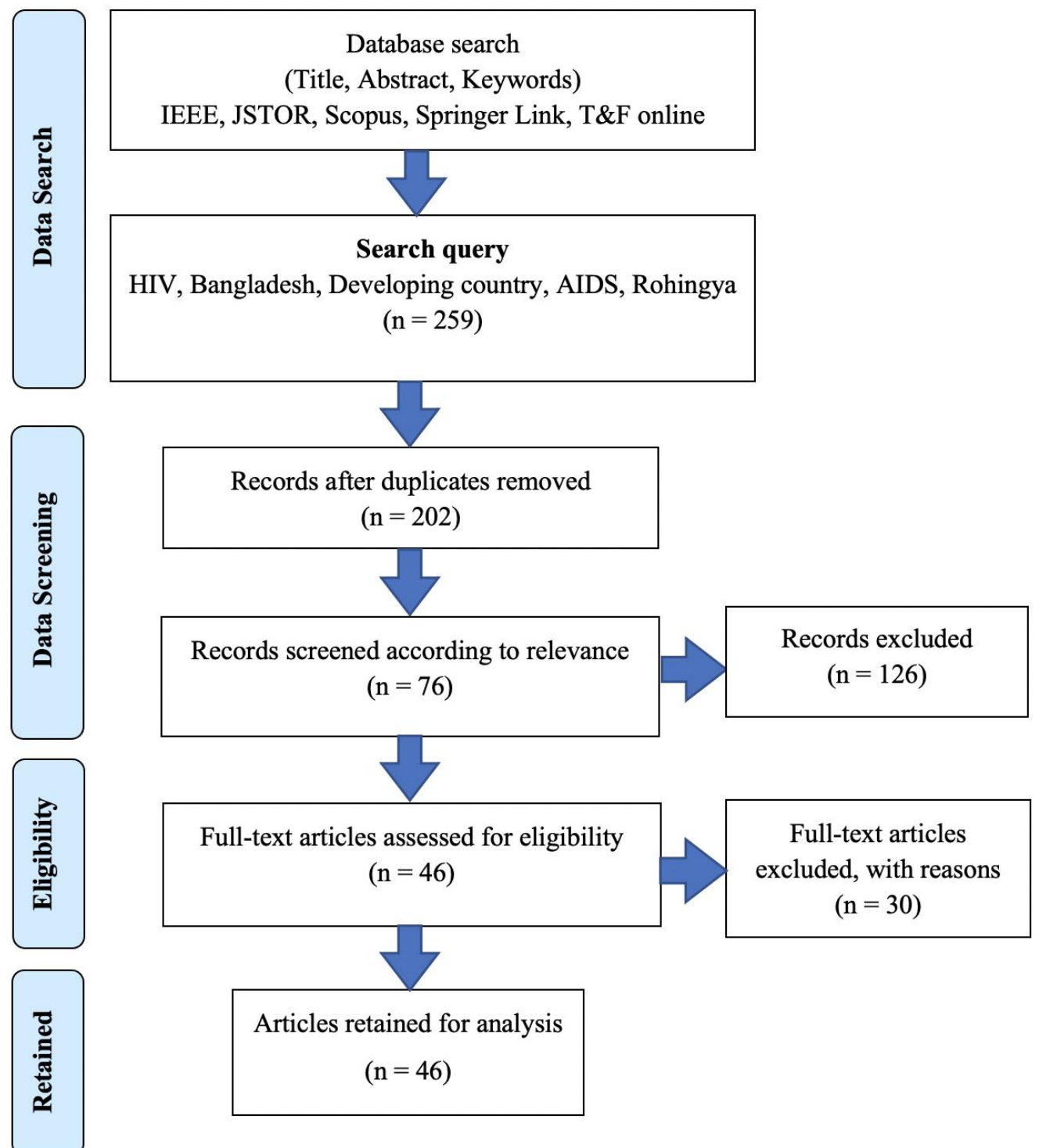

Figure 3: PRISMA flow diagram 
INTERNATIONAL JOURNAL OF ACADEMIC RESEARCH IN BUSINESS AND SOCIAL SCIENCES Vol. 11, No. 5, 2021, E-ISSN: 2222-6990 @ 2021 HRMARS

Table 1. Review of significant studies HIV/AIDS studies in Bangladesh

\begin{tabular}{|c|c|c|}
\hline Study & Objective & Conclusion \\
\hline $\begin{array}{l}\text { Ahasan, } \\
\text { Hossain, \& } \\
\text { Reza, (2018) }\end{array}$ & $\begin{array}{l}\text { To assess the status of Antiretroviral } \\
\text { Therapy (ART) in Bangladesh }\end{array}$ & $\begin{array}{l}\text { Urge for (a) substantial investment in facility improvement and } \\
\text { continuance, (b) addressing focus groups such as migrants, children } \\
\text { with HIV properly, (c) look for the effective measure to overcome } \\
\text { legal and social barriers. }\end{array}$ \\
\hline $\begin{array}{l}\text { Sarma et al. } \\
\text { (2017) }\end{array}$ & $\begin{array}{l}\text { To assess the HIV/AIDS-related } \\
\text { knowledge, attitudes, and behaviors } \\
\text { among students }\end{array}$ & $\begin{array}{l}\text { Curriculum upgrading regarding self-risk perception, scaling up a } \\
\text { training program, a nationwide pre-post study assessing knowledge } \\
\text { level. }\end{array}$ \\
\hline Yaya (2016) & $\begin{array}{l}\text { To unearth the influential factors of HIV } \\
\text { knowledge in Bangladesh. }\end{array}$ & $\begin{array}{l}\text { Significant investment. Despite being aware of HIV, people have } \\
\text { too little understanding of how it transmits; thus, substantial } \\
\text { financial and logistic investment is needed in increasing awareness. }\end{array}$ \\
\hline $\begin{array}{l}\text { Urmi et al. } \\
\text { (2015) }\end{array}$ & $\begin{array}{l}\text { To identify risk factors for HIV positivity a } \\
\text { mong returning migrants workers }\end{array}$ & $\begin{array}{l}\text { Migrant workers group and intervention are required, and their } \\
\text { spouse needs specific focus as they noticeably contribute to } \\
\text { increasing the number of HIV infection in the country. }\end{array}$ \\
\hline $\begin{array}{l}\text { Khan et al. } \\
\text { (2019) }\end{array}$ & Assessing the HIV status among IDUs & $\begin{array}{l}\text { Treatment and health services for IDUs are required. Also, } \\
\text { information on HIV occurrence, protective measures, mental } \\
\text { health, an empirical study is lacking that needs improvement. }\end{array}$ \\
\hline $\begin{array}{l}\text { Hsan et al. } \\
\text { (2019) }\end{array}$ & $\begin{array}{l}\text { Assessing the HIV status among Rohingya } \\
\text { refugees }\end{array}$ & $\begin{array}{l}\text { Extensive behavioral change programs, allied preventive measures, } \\
\text { such as social protection, preventing drug use, restricting forced } \\
\text { prostitution, and empowering health professionals prioritizing HIV } \\
\text { prevention Are suggested. }\end{array}$ \\
\hline $\begin{array}{l}\text { Haque et al. } \\
(2018)\end{array}$ & $\begin{array}{l}\text { To assess the awareness level among } \\
\text { married women regarding HIV }\end{array}$ & $\begin{array}{l}\text { Mass media, schools, religious entities, workplaces can be utilized } \\
\text { for the awareness campaign. A resilient social movement to } \\
\text { prevent HIV/AIDS is a must. }\end{array}$ \\
\hline $\begin{array}{l}\text { Mahmood } \\
(2020)\end{array}$ & $\begin{array}{l}\text { To examine the impact of violence in } \\
\text { increasing vulnerability towards HIV } \\
\text { among Bangladeshi women. }\end{array}$ & $\begin{array}{l}\text { Urge for policy development for women's safety against violence. } \\
\text { Counseling and sexual education facility development is } \\
\text { encouraged. }\end{array}$ \\
\hline
\end{tabular}


INTERNATIONAL JOURNAL OF ACADEMIC RESEARCH IN BUSINESS AND SOCIAL SCIENCES

Vol. 11, No. 5, 2021, E-ISSN: 2222-6990 @ 2021 HRMARS

\begin{tabular}{|c|c|c|}
\hline $\begin{array}{l}\text { Islam, } \\
\text { Minichiello, \& } \\
\text { Scott (2019). }\end{array}$ & $\begin{array}{l}\text { To understand the concept of resilience } \\
\text { among the people living with HIV. }\end{array}$ & $\begin{array}{l}\text { Self-help groups, culturally appropriate interventions to assist the } \\
\text { HIV infected parents and their children }\end{array}$ \\
\hline $\begin{array}{l}\text { Sheikh, Uddin, \& } \\
\text { Khan (2017) }\end{array}$ & $\begin{array}{l}\text { to assess the knowledge level and } \\
\text { understanding of pattern, factors linked to } \\
\text { HIV/AIDS among Bangladeshi women. }\end{array}$ & $\begin{array}{l}\text { Recommends effective awareness program via mess media, family } \\
\text { education (women and her partner). }\end{array}$ \\
\hline $\begin{array}{l}\text { Faruk, Begum \& } \\
\text { Rana, (2017) }\end{array}$ & $\begin{array}{l}\text { To understand the level and trends } \\
\text { towards the HIV/AIDS epidemic and } \\
\text { awareness in Bangladesh. }\end{array}$ & $\begin{array}{l}\text { The government initiated awareness programs, intervention } \\
\text { strategies are required. }\end{array}$ \\
\hline $\begin{array}{l}\text { Sahani, Islam \& } \\
\text { Biswas, (2017) }\end{array}$ & $\begin{array}{l}\text { To understand the significance of HIV } \\
\text { infection implying mathematical modeling } \\
\text { technique }\end{array}$ & $\begin{array}{l}\text { The low prevalence rate is increasing, which is a matter of } \\
\text { apprehension. }\end{array}$ \\
\hline $\begin{array}{l}\text { Nahar et al. } \\
\text { (2017) }\end{array}$ & $\begin{array}{l}\text { To assess the knowledge level of socio- } \\
\text { demographic factors and their impact } \\
\text { among IDUs. }\end{array}$ & $\begin{array}{l}\text { Practical strategies for harm reduction, education, knowledge } \\
\text { increasing about HIV/AIDS among IDUs are needed. }\end{array}$ \\
\hline $\begin{array}{l}\text { Afroz et al. } \\
(2020)\end{array}$ & $\begin{array}{l}\text { To comprehensively study the challenges } \\
\text { faced by children affected or infected by } \\
\text { HIV/AIDS (CABA) because of parents' } \\
\text { HIV/AIDS status. }\end{array}$ & $\begin{array}{l}\text { Ensuring educational facilities for CABA by increasing government } \\
\text { support (i.e., financial, educational, treatment, skill-developing for } \\
\text { generating income) is necessary to thrive. }\end{array}$ \\
\hline $\begin{array}{l}\text { Rahman et al. } \\
(2018)\end{array}$ & $\begin{array}{l}\text { To determine the frequency of } \\
\text { malnutrition and HIV, categorize the allied } \\
\text { factors }\end{array}$ & $\begin{array}{l}\text { Educating adolescence, cost-effective infrastructure development, } \\
\text { strategy reform, capacity-building for HIV prevalence is suggested. } \\
\text { Also, social media, training health professionals for better } \\
\text { treatment, and teachers for increasing awareness among the youth } \\
\text { population have been recommended. }\end{array}$ \\
\hline $\begin{array}{l}\text { Hossain et al. } \\
\text { (2018) }\end{array}$ & $\begin{array}{l}\text { Identifying diverse risk factors among HIV } \\
\text { patients }\end{array}$ & A counseling facility regarding high-risk behavior is necessary. \\
\hline
\end{tabular}


INTERNATIONAL JOURNAL OF ACADEMIC RESEARCH IN BUSINESS AND SOCIAL SCIENCES

Vol. 11, No. 5, 2021, E-ISSN: 2222-6990 @ 2021 HRMARS

\begin{tabular}{|l|l|l|}
\hline $\begin{array}{l}\text { Geibel et al. } \\
(2017)\end{array}$ & $\begin{array}{l}\text { Evaluation of a training program for health } \\
\text { professionals }\end{array}$ & $\begin{array}{l}\text { Interventions to reduce stigma among health professionals through } \\
\text { participatory training programs are recommended. }\end{array}$ \\
\hline Rashid (2017) & $\begin{array}{l}\text { To assess the knowledge level, influential } \\
\text { factors associated with HIV among } \\
\text { adolescents students. }\end{array}$ & $\begin{array}{l}\text { The overall level of knowledge is low, particularly among females, } \\
\text { thus requiring scale-up programs that circulate comprehensive } \\
\text { information and knowledge and increase communication among } \\
\text { high school students and rural communities. }\end{array}$ \\
\hline
\end{tabular}




\section{Government and other Initiatives}

The government of Bangladesh (GOB) is working for the HIV/AIDS prevalence and several local and international NGOs science 1989. With the financial support from Global Fund, MOHFW (Ministry of Health and Family Welfare), GOB launched an HIV prevention intervention project named "Prevention of HIV/AIDS among Young People in Bangladesh." Moreover, the project combines AIDS prevention, including awareness increasing information through print and mass media, evidence-based education in the classroom setting, friendly health services, social marketing strategy on the accessibility of condoms, a support program for parents with the help of religious and community leaders. Programmatic intervention for camping under the tag line "Bachteholey Jante Hobe" (If you want to live, you have to know) is going on till now. "AIDS ki? Bachte holey, Jante Hobey" (what is AIDS? If you want to live, you have to know) TVC is being telecasted from December 2004 (Mattrabd, 2018).

GoB established NAC (National AIDS Committee) in 1995 for policymaking by addressing HIV/AIDS-related issues. The NASP (National AIDS/STD Programme) under MOHFW primarily focuses on behavior-change interventions. Nationwide, HIV/AIDS prevention programs are performed with management assistance from UNICEF (United Nations Children's Fund), WHO (World Health Organization), and UNFPA (United Nations Fund for Population Activities). Approximately $400 \mathrm{NGOs}$ are running several HIV/AIDS intervention programs through the quality of services are sometimes questionable as they have resource limitation. 'Prevention of HIV/AIDS amongst younger humans in Bangladesh' is one of the interventions taken by the government since 2007.

Moreover, the program aims to enhance the level of knowledge and awareness among the young generation. The book chapter has been included in the national textbook from Grade VI to XII (Huda \& Ferdous, 2018). Hence, it is expected that each year, around 11 million students will receive adequate knowledge regarding HIV/AIDS under this nationwide project. Teachers, governing body members, institutions have been trained for the sustainability of this curriculum-based intervention. PIACT a non-profit NGO working together with GoB. They are running a teachers training program since 2004 for capacity building among the school teachers who are involved in teaching about HIV/AIDS in a classroom setting. (Sarma et al., 2017). "Nijeke Jano" (Know yourself) is a booklet series on youths' reproductive health information. The intervention initiative was taken in 2002, and regularly it's being updated (ICDDRB, 2019). MoHFW (Ministry of Health and Family Welfare) reviewed the last edition of the booklet in January 2015. MoHFW also conducts workshop for youths'

\section{HIV/AIDS Treatment}

GoB is providing HIV/AIDS treatment facilities using the national fund for a limited number of patients, commenced by ICDDR-B for the last 14 years. ART program was first initiated in 2008 with the support of GFATM (NSAP, 2018). GBD is facilitating the ART program since 2012 (NSAP, 2018). NASP of Bangladesh (National AIDS/STD Programme) offers VCT via twelve hospital-based drop-in-centers (DICs). NGOs (Non-governmental organizations) and $\mathrm{CBOs}$ (community-based organizations) provide HIV testing facilities to a limited number of key populations (KPs) with support from the GFATM. Sentinel surveillance being provided among PWIDs (Persons Who Inject Drugs), MSM (men who have sex with 
men) and, FSW (female sex worker) since 2011 (Rezwan et al., 2016). Another NGO called Bandhu Social Welfare Society offers an HIV testing facility for MSM and transgender (TGs) populations. Pediatric HIV treatment also having very insufficient centers and can take care of only two hundred kids to be diagnosed and treated (NSAP, 2018).

\section{Treatment and Policy Gap}

HIV incidence among the general population in Bangladesh is still low, and therefore, it has not been taken under critical situations (Rezwan et al., 2016). Despite incriminating in the number of patients on ART (Antiretroviral therapy), the treatment gap is increasing, as shown in Figure 3. The ART response rate was only 1,800 in 2016 increased to 2,500 in 2017 (Hsan et al., 2019).

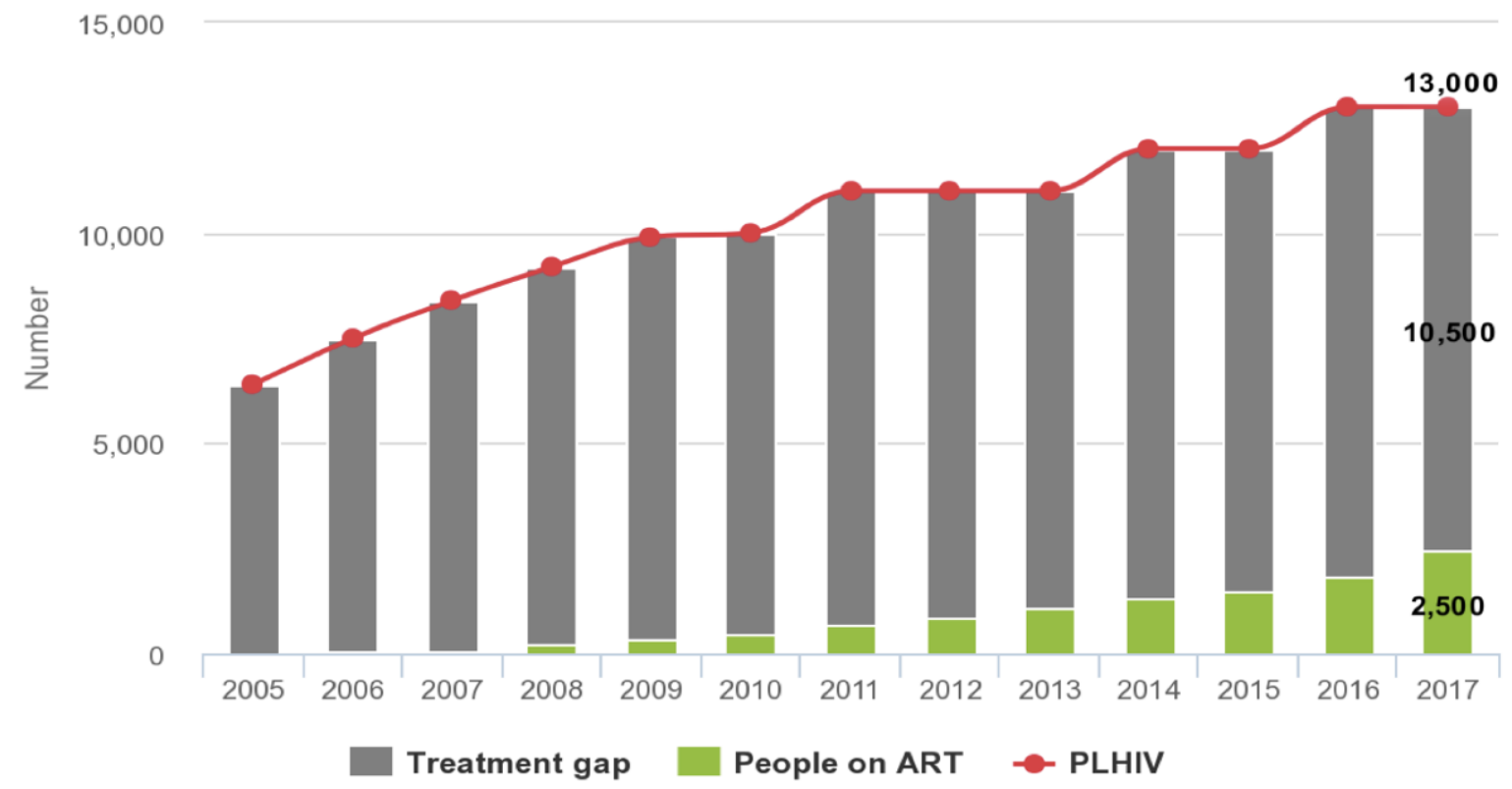

Figure 4: People living with HIV, people on ART and treatment gap, 2005-2017 (Aidsdatahub, 2018)

Pregnant women are also examined for HIV. Although, the sexual health clinics are not presenting HIV check-up and testing facilities (NASP, 2014). There are around 95,000 MSM $(40,000-150,000)$ who live in Bangladesh, and 1\% are HIV positive. Approximately 40,000 of them could be protected via the GFATM. Despite that, only 35\% of MSM was examined for HIV. Half of the MSM are married to woman partners. No interventions or testing facilities are in place for their spouses (Rezwan et al., 2016), even though very few confined facilities are accessible for identifying Ols (opportunistic infections) and coinfections. Moreover, checking for and STI (Sexually Transmitted Infection) offerings inaccessible. As a result, medical resources in Bangladesh are gradually reducing for HIV prevention, testing, and STI offerings.

Moreover, many protective measures were taken to preserve the human right of PLHIV to ensure that confidentiality does not become a barrier toward searching for HIV healthcare facilities (Tran, 2012). HIV testing and counseling facilities are not coupled together to ease the stigma of this life-threatening disease. Stigma linked to HIV creates refraining behavior among couples from taking counseling sessions and HIV testing. 
Moreover, there is no policy for HIV testing or structured HIV prevention program for returning migrants. Lack of structured and dependent HIV anticipation among migrants is a disadvantage of the HIV detection and prevention system (Urmi, Leung \& Wilkinson, 2015). Hence, the treatment gap is not the only reason behind HIV prevalence and the massive fatality of AIDS.

The weakness of the healthcare system is threatening for healthcare quality improvement of the general population. HIV checking out is performed in MDR (multidrug-resistant) and remedy failure amongst Tuberculosis (TB) patients. High-risk groups such as PWIDs, MSM, FSW were underneath sentinel surveillance insurance till 2011 (NASP, 2014). Bangladesh is currently relying on external resources for HIV care and facilities as high as $84 \%$, and treatment coverage also remains low (Koirala, 2017). A study from Bangladesh determined that $80 \%$ of the nurses and $90 \%$ of the physicians behaved discriminatory towards PLHIV. In addition, the insurance policy does not provide coverage for PLHIV in Bangladesh (Koirala, 2017). The government and many NGOs have taken several initiatives; however, the treatment gap could not be reduced. Despite that, regular HIV examination is not available due to the low HIV incidence among the general population (Rezwan et al., 2016) of Bangladesh.

\section{Resource Limitation}

Limitation of resources is another drawback for the HIV-related healthcare service. Two HIV viral load testing and eight CD4 T cell are not functioning due to the limited resources in Bangladesh. Moreover, healthcare budget allocation is continually shrinking in Bangladesh. In the last seven economic years, healthcare expenditure budgetary allocation government expenditure for the healthcare sector decreases trend as the funding dropped from $6.2 \%$ to $4.3 \%$. Inadequate public spending creating a catastrophic impact on the general population as the OOP (out-of-pocket payment) is approximately 65\% (Hassan et al., 2016). The Healthcare sector is heavily dependent on international organizations or development partners. Healthcare Insurance almost doesn't exist in the country. Even though a few NGOs have channeled the medical insurance schemes in recent years, it will take some time to benefit the entire population. In addition, many NGOs are also closing down due to the lack of human resources and financial support (Rezwan et al., 2016). Hence, the healthcare system in Bangladesh is entirely dependent on its government for financial assistance, service policy, and delivery mechanism determination and set up.

World Health Organization (WHO) has highlighted some challenges in Bangladesh for successful HIV/AIDS running prevention intervention. Although HIV prevalence is currently low, the number of people with HIV infection can be increased. HIV infection can increase among IDU and Bangladesh workers in foreign countries engaged in unsafe sex activities. Despite the minor scale of supporting services regarding treatment and care and ART related to HIV/AIDS positives is available in Bangladesh. Moreover, the Bangladesh government setting is so complicated; to establish VCT services across the country. Quality treatment is required, including ARVs, as demand and need for these services are increasing. Hence, strengthening the government healthcare system in technical expertise is a must for diagnosis and treatment. Bangladesh needs a lot of experts in this field (WHO, 2018). 


\section{Key Population}

\section{Injecting drug users (IDU)}

Drug abuse is imperative social trouble growing public fitness problems in Bangladesh. Bangladesh is in an inclined situation due to its geographical alignment. The country is surrounded by 'golden crescent' (Pakistan, Iran, Afghanistan) and 'golden triangle' (Laos, Thailand, Myanmar) known for the drug. Due to geographical vulnerability, drug abuse cases are growing extensively. The risk of getting infected is three times higher among IDUs due to needle sharing than sexual transitions (Nahar et al., 2017). IDUs are the highest contributors of HIV/AIDS and contamination in Bangladesh (Rezwan et al., 2016). Despite that, only a few NGOs are facilitating HIV testing for IDUs since 1998. The HIV treatment and testing uptake rate among IDUs in Bangladesh is only 5\% (Rezwan et al., 2016).

\section{Transgender}

There is no HIV routine check and check-up available for the 10,000 transgender (TG or Hijra) population. According to the survey report of 4th round behavioral survey report, $0.8 \%$ of TGs have HIV infection as they are sexually abused. A community affiliation named "Bandhu Social Welfare Society" has involvement in HIV testing intervention programs amongst TGs, but that's not adequate (BHS, 2017; Rezwan et al., 2016). Transgender (TGs) or hijras aren't inclined to go for remedy. Currently, prevention and HIV testing coverage is $46 \%$ and $35 \%$, respectively, as shown in Figure 4.

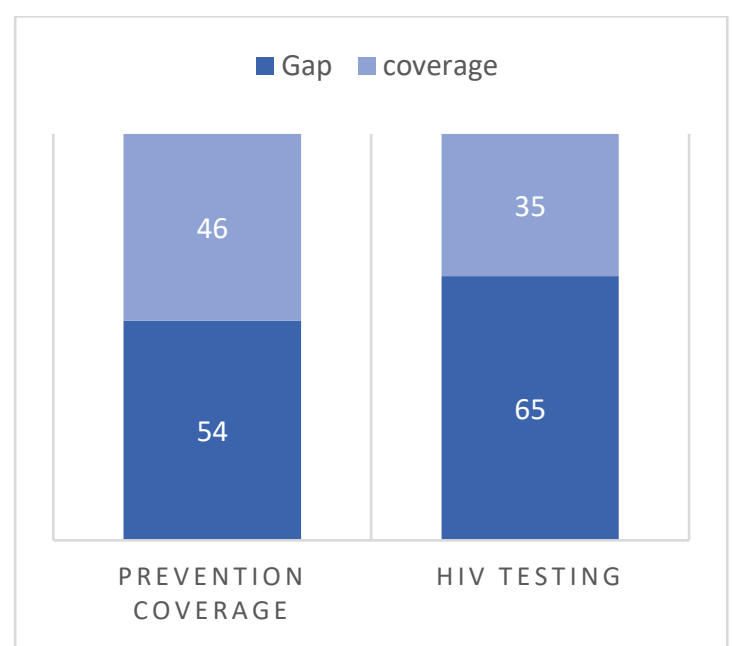

Figure 5:HIV prevention and testing coverage among transgender women ( $\mathrm{Hijra}$ ) in Bangladesh (BHS, 2017)

\section{Rohingya}

Rohingya displaced society has been appearing in Bangladesh since the late 1970s. Previously, Rohingya people had been displaced into the country in 1978 and 1991-1992, approximately by 2 to 2.6 million respectively (Mahmood, Wroe \& Fuller, 2017). Recent displacement of more than four (4) million Rohingya refugees, Bangladesh has been recognized as World's biggest refugee camp (White, 2017). Bangladesh is a haven for 950,000 Rohingya refugees living in Myanmar-Bordered-Cox's Bazar (ICDDRB, 2017). This population has many health issues that are alarming for the country; HIV/AIDS is a significant concern (Beyrer \& Kamarulzaman, 2017). Myanmar has been recognized as the second highest $(0.8 \%$ of the population) HIV prevalence country in South East Asia. In 
2016, more than 250,000 people of Myanmar were estimated to have HIV infection. The estimated total number of 50,000 Rohingya dwelling with HIV (Islam, 2018).

GoB and NGOs are endeavoring their best to offer healthcare services to homeless refugees. October 30, 2017, sixty-one HIV-positive Rohingya people were identified. By June 23, 2018, the Health minister mentioned another sixty-three HIV-positive Rohingya patients had been identified. Moreover, at the least eighty-three cases of HIV have been said within the camp to date (Islam, 2018). Approximately a million Rohingya people are residing in the refugee camp in Cox's Bazar, Bangladesh. In March 2019, 319 HIV cases were recorded, and 19 died (Hsan et al., 2019). Despite that, many other Rohingya refugees, especially ladies and girls, have been abused in Myanmar; and have a high chance of having HIV/AIDS infection. ICDDR-B and ASP (AIDS/STD Programme) are working together to run HIV/AIDS Programme (ICDDRB, 2017; Beyrer \& Kamarulzaman, 2017).

\section{Discussion}

The risk of HIV infection is still high due to numerous factors, specifically the high occurrence of TB, STI, and Hepatitis B+, more than one sex partners, marginalized group, high levels of transactional sex, unsafe blood donor, price excessive, low condom use rate (BHS, 2017). Again, few berries that need immediate attention include (a) vulnerability among injecting drug users (IDUs), (b) lack of voluntary counseling, (c) shortage of healthcare facilities, (d) lack of awareness, (e) gender inequality, ( $f$ ) overpopulation of FSWs, MSM, (g) social stigma, (h) facilitative prison environment is. Moreover, several degrees of exclusion among high-risk groups is the reason behind the increasing number of HIV infection and AIDS-related death (Khosla, 2009).

Hence, interventions that include mobile VCT (Voluntary Counselling and Testing) centers must be studied and applied to promote HIV testing (Rezwan et al., 2016). Improving the acceptance and attempt level for HIV testing can be achieved through providing friendly service. NASP should have additional concern on developing a sustainable healthcare model to serve HIV patients and high-risk groups. WHO guiding for ART needs to be followed accordingly for full coverage of KPs (Rezwan et al., 2016). The behavioral intervention has to be coupled with HIV testing. CBOs intervention programs along with condom distribution for FSWs need to be scaled up. Measures need to be taken to illuminate confusion and misconception on HIV/AIDS so that people do not get involved in any unstable behavioral misconduct (Rezwan et al., 2018).

Hence, to reduce or eliminate the HIV/AIDS suffering, some interventions are suggested by the researchers. Authorities in Bangladesh must establish public talk about healthcare facilities for HIV/AIDS, as it can be avoided if not cured at the moment. Hence, identifying focus groups that are vulnerable to HIV should be the priority with the exact number of people belongs to that groups of behavior change intervention-engaging in advocacy and focus and counseling applications via multi-sectoral businesses. Projects for flourishing social acceptability of condom use, easing stigma, lowering discrimination have to be prioritized (Rezwan et al., 2018). An adequately designed systematic approach must be taken to deal with HIV/AIDS prevention (Islam, 2018).

People living with HIV need to be treated appropriately in terms of treatment, services, and behavior of the people living in the society. Capacity building for program planning, monitoring the implemented intervention, management process needs to be strengthened both at the national and NGO level. Media-based intervention activities can 
play a vital role in creating awareness. Traditional media like TV, radio, the newspaper have already been utilized for HIV/AIDS camping. Social media can be a part of such an awareness program. Due to peer effete, youth tends to follow their peers or friend. Peers can be trained to spread awareness among others. Peers have a significant influence on adolescents. The Muslim majority (approximately 90\%) can be utilized positively by designing programs like religious leaders who teach or talk on HIV/AIDS to the parents for healthy life skill improvement. Producing quality and systematic research is required to get updated and reliable data regarding HIV/AIDS occurrence, prevention, intervention success. A trusted source of information is a prerequisite for appropriate policies and programs to be developed and intervention. Although there is no alternative to increasing the healthcare service facilities but HIV/AIDS is associated with social stigma, level of awareness, poor treatment uptake rate, unwillingness for HIV testing so on and so forth. Therefore, the ministry of health cannot uproot the HIV/AIDS problem all alone. More, NGOs should come forward and extend their help to make Bangladesh a free country of HIV/AIDS disease.

Hence, it's a real challenge for a nation to fight back with such types of diseases that require a combined, integrated activity to be eased. Although, the "Multisector Approach" is appreciated for non-communicable diseases according to WHO (SDG). Although, the "Multisector approach" is favored for non-communicable diseases in step with WHO (SDG). Understanding the nature of the HIV/AIDS incidence, the "Multisector approach" is strongly recommended for HIV/AIDS prevention through HIV/AIDS is a noncommunicable disease. There is no alternative way to end the death toll by implementing the "Multi-sector Approach" for HIV/AIDS prevention. Hence, the study suggests that a total number of fourteen (14) ministries of Bangladesh need an integrative intervention approach that includes; Ministry of Finance, Ministry of Health and Family Welfare, Ministry of Local government and Rural Development and Co-operative, Ministry of Religious Affairs, Ministry of Home Affairs, Ministry of Information, Ministry of Education, Ministry of law, justice, and Parliamentary Affairs, Ministry of Public Administration, Ministry of Primary and Mass Education, Ministry of Planning, Ministry of Social welfare, Ministry of Youth and Sports, Ministry of Women and Children Affairs. Sex education in learning institutions, healthcare awareness among all members of society, legal and ethical practice, proper law enforcement could uproot HIV/AIDS from the country. Therefore, it is expected that this approach will bring visible success compared to the silo method of intervention.

\section{Limitation and Future Research Direction}

This paper used only available secondary data available via scholarly databases but government, NGO generated reports could not be assessed. The extreme shortage of secondary data caused a lack of evidence demonstrability in this study. Thus, more rigorous empirical and secondary research is required in this phenomenon. Primary statistical data could not be gathered. Data about high-risk groups are also insufficient. Therefore, this researcher relied heavily on the WHO, The Joint United Nations Programme on HIV/AIDS (UNAIDS) reports for data.

\section{Conclusion}

This research contributes to the knowledge as there are limited studies on this particular phenomenon in the Bangladesh context. Also provides information and suggestion for 
practical implication for policymaking. Thus the study can guide further research in another developing country context.

However, there are numerous active NGOs and community-based organizations (CBOs) in Bangladesh. HIV prevention programs are aided mainly by these NGOs and CBOs with external funding. Social ignorance and conceptual gap derived from religious aspects make the situation more critical and vulnerable for the transgender population. Lack of social awareness and acceptance toward HIV patients, shortcoming on understanding, and conceptual gap derived from religious aspects make the situation more critical and vulnerable to the ease of HIV/AIDS (HBS, 2017).

\section{References}

Afroz, T., Camellia, S., Oyewale, T., Uddin, M. Z., \& Mahmud, I. (2020). Role of the HIVsensitive protection services in mitigating the challenges and vulnerability of the children affected by HIV/AIDS in Bangladesh: a qualitative study. medRxiv.

AIDSdatahub. (2018). http://www.aidsdatahub.org/Country-Profiles/Bangladesh . Retrieved from aidsdatahub: http://www.aidsdatahub.org/Country-Profiles/Bangladesh

Avert. (2018). Retrieved April 19, 2019, from https://www.avert.org/professionals/hivaround-world/asia-pacific/overview

Ahasan, H. N., Hossain, H. T., \& Reza, I. B. (2018). Current Status of Antiretroviral Therapy (ART) for Acquired Immunodeficiency Syndrome (AIDS) in Bangladesh. Journal of Bangladesh College of Physicians and Surgeons, 36(3), 118-122.

Azim, T., Bontell, I., \& Strathdee, S. A. (2015). Women, drugs and HIV. International Journal of Drug Policy, 26, S16-S21.

BHS . (2017). A brief senario of Hijra (Transgender) people in Bangladesh.

Choudhary, M. S. R., \& Rahman, M. M. (2014). Knowledge, awareness and perception about HIV/AIDS among primary school teachers in Bangladesh. Bangladesh Journal of Medical Science, 13(2), 145-149.

Das, A. C. (2017). HIV epidemic Situation in Bangladesh: An Ocerview. 07(2).

Fang, D., Sun, R., \& Wilson, J. R. (2018). Joint modeling of correlated binary outcomes: The case of contraceptive use and HIV knowledge in Bangladesh. PloS one, 13(1), e0190917.

Faruk, O., Begum, N., \& Rana, S. (2017). Trends of HIV/AIDS epidemic and awareness levels in Bangladesh. International Journal on Data Science and technology, 6, 56-65.

Garai, J. (2016). Gender and hiv/aids in bangladesh: A review. J Health Soc Sci, 1(3), 181-98.

Geibel, S., Hossain, S. M., Pulerwitz, J., Sultana, N., Hossain, T., Roy, S., ... \& Yam, E. (2017). Stigma reduction training improves healthcare provider attitudes toward, and experiences of, young marginalized people in Bangladesh. Journal of Adolescent Health, 60(2), S35-S44.

Gisslen, M., Svedhem, V., Lindborg, L., Flamholc, L., Norrgren, H., Wendahl, S., \& Sönnerborg, A. (2017). Sweden, the first country to achieve the Joint United Nations Programme on HIV/AIDS (UNAIDS)/World Health Organization (WHO) 90-90-90 continuum of HIV care targets. HIV medicine, 18(4), 305-307.

Gupta, S., Williams, B., \& Montaner, J. (2014). Realizing the potential of treatment as prevention: global ART policy and treatment coverage. Current HIV/AIDS Reports, 11(4), 479-486. 
Hassan, M. Z., Fahim, S. M., Zafr, A. H. A., Islam, M. S., \& Alam, S. (2016). Healthcarefinancing in Bangladesh: challenges and recommendations. Bangladesh Journal of Medical Science, 15(4), 505-510.

HIV and AIDS data hub for asia pasific. (n.d.). Evidence to action . Retrieved from http://www.aidsdatahub.org/Country-Profiles/Bangladesh

Hossain, M. M., Sultana, A., \& Mazumder, H. (2018). Sexually transmitted infections among Rohingya refugees in Bangladesh. The Lancet HIV, 5(7), e342.

Hossain, M., Mani, K. K., Sidik, S. M., Shahar, H. K., \& Islam, R. (2014). Knowledge and awareness about STDs among women in Bangladesh. BMC public health, 14(1), 775.

Hossain, M. J., Siddiqi, M. A., Rahman, M. M., Khan, K. N., \& Imtiaj, A. (2018). A clinical study on genital warts and HIV in Bangladesh. International Journal, 4(1), 5.

Hsan, K., Griffiths, M. D., Gozal, D., \& Rahman, M. A. (2019). HIV infection in Rohingya refugees in Bangladesh. The Lancet HIV, 6(7), e419.

Haque, M. A., Hossain, M. S. N., Chowdhury, M. A. B., \& Uddin, M. J. (2018). Factors associated with knowledge and awareness of HIV/AIDS among married women in Bangladesh: evidence from a nationally representative survey. SAHARA-J: Journal of Social Aspects of HIV/AIDS, 15(1), 121-127.

Huda, M. N., \& Ferdous, A. (2018). The impact of HIV/AIDS education through formal curriculum and texts in Bangladesh: A study on secondary and higher secondary students. International Journal of Perceptions in Public Health, 2(2), 94-107.

ICDDRB. (2017). Global Health Insights . initiatives-in-response-to-hiv-prevention-inbangladesh.

ICDDR-B. (2019). Retrieved 18 April, 2019, from https://www.icddrb.org/research/researchthemes/maternal-and-neonatal-health/impact.

Islam, N. (2018). The international medical community must act to help Rohingya refugees in Bangladesh.

Islam, M. J., Hossain, M. M., Rahman, S., \& Hasan, M. Z. (2018). Factors Determining Knowledge of HIV/AIDS among Bangladeshi Women. Global Journal of Medical Research.

Islam, M. S., Minichiello, V., \& Scott, J. (2019). Resilience strategies of HIV-positive parents who live with children within the family context in Bangladesh. AIDS care, 31(3), 310313.

Jones, J., Sullivan, P. S., \& Curran, J. W. (2019). Progress in the HIV epidemic: Identifying goals and measuring success. PLoS medicine, 16(1), e1002729.

Kabir, H., Saha, N. C., Wirtz, A. L., \& Gazi, R. (2014). Treatment-seeking for selected reproductive health problems: behaviours of unmarried female adolescents in two lowperforming areas of Bangladesh. Reproductive health, 11(1), 54.

Kamruzzaman, M., \& Hakim, M. A. (2016). Condom Using Prevalence and Phobia on Sexually Transmitted Diseases Among Sex-Buyers in Bangladesh. American Journal of Environmental and Occupational Health, 1(1), 1-5.

Khan, S. I., Reza, M. M., Crowe, S. M., Rahman, M., Hellard, M., Sarker, M. S., ... \& Ross, A. G. (2019). People who inject drugs in Bangladesh-The untold burden!. International Journal of Infectious Diseases, 83, 109-115.

Khosla, N. (2009). HIV/AIDS Interventions in Bangladesh: What Can Application of a Social Exclusion Framework Tell Us? International center for diarrhoeal disease research, Bangladesh, 27. 
Koirala, S., Deuba, K., Nampaisan, O., Marrone, G., \& Ekström, A. M. (2017). Facilitators and barriers for retention in HIV care between testing and treatment in Asia-A study in Bangladesh, Indonesia, Lao, Nepal, Pakistan, Philippines and Vietnam. PloS one, 12(5), e0176914.

Mahmood, S. (2020). Female Garment Workers in Bangladesh: Violence, Gender and HIV/AIDS. AIDS (2020). Journal of Social and Political Sciences, 3(2).

Mondal, M. N. I., Hoque, N., Chowdhury, M. R. K., \& Hossain, M. S. (2014). Factors Associated with Misconceptions about HIV Transmission of Ever-Married Women in Bangladesh. Japanese journal of infectious diseases, JJID-2013.

Mattrabd. (2018). Retrieved April 18, 20019, from https://mattrabd.com/cubeportfolio/aidscampaign/.

Nahar, N., Akter, J., Mahbub, M. S., Sultana, R., Khan, F. I., Faruque, M., \& Ara, B. R. (2017). Association of socio-demographic issues with level of knowledge of HIV/AIDS among injecting drug users in Dhaka City in Bangladesh. South East Asia Journal of Public Health, 7(1), 42-47.

NSAP. (2018). Dhaka, Bangladesh: Ministry of Health and Family Welfare, Directorate General of Health Services, NASP. Available at: www.aidsdatahub.org/sites.

NASP . (2014). (National AIDS/STD Programme) Assessment of impact of harm reduction interventions among people who inject drugs (PWID) in Dhaka city. 2014.

O'Reilly, K. R., d'Aquila, E., Fonner, V., Kennedy, C., \& Sweat, M. (2017). Can policy interventions affect HIV-related behaviors? a systematic review of the evidence from low-and middle-income countries. AIDS and Behavior, 21(3), 626-642.

Rahman, A. M., Hasan, M., Rahman, M. A., \& Afrose, T. (2018). Malnutrition and hiv/aids: the most threatening concerns in Bangladesh.

Rashid, A. (2017). P4.01 Assessment of comprehensive hiv/aids knowledge level among inschool $\ \&$ community level adolescents of noakhali and lakshmipur district, bangladesh. Sexually Transmitted Infections, 93(Suppl 2), A192--A192. https://doi.org/10.1136/sextrans-2017-053264.498

Rezwan, K., Khan, H. S., Azim, T., Pendse, R., Sarkar, S., \& Kumarasamy, N. (2016). A success story: identified gaps and the way forward for low HIV prevalence in Bangladesh. Journal of virus eradication, 2(Suppl 4), 32.

Saeed, S., Strumpf, E. C., Walmsley, S. L., Rollet-Kurhajec, K., Pick, N., Martel-Laferrière, V., \& Klein, M. B. (2016). How generalizable are the results from trials of direct antiviral agents to people coinfected with HIV/HCV in the real World?. Clinical Infectious Diseases, 62(7), 919-926.

Sarma, H., Islam, M. A., Khan, J. R., Chowdhury, K. I. A., \& Gazi, R. (2017). Impact of teachers training on HIV/AIDS education program among secondary school students in Bangladesh: A cross-sectional survey. PloS one, 12(7), e0181627.

Sahani, S. K., Islam, A., \& Biswas, M. H. A. (2017). Mathematical Modeling Applied to Understand the Host-Pathogen Interaction of HIV Infection in Bangladesh. Surveys in Mathematics and its Applications, 12, 165-178.

Shahrin, L., Leung, D. T., Matin, N., Pervez, M. M., Azim, T., Bardhan, P. K., \& Chisti, M. J. (2014). Characteristics and predictors of death among hospitalized HIV-infected patients in a low HIV prevalence country: Bangladesh. PloS one, 9(12), e113095.

Sheikh, M. T., Uddin, M. N., \& Khan, J. R. (2017). A comprehensive analysis of trends and determinants of HIV/AIDS knowledge among the Bangladeshi women based on 
Bangladesh Demographic and Health Surveys, 2007-2014. Archives of Public Health, 75(1), 1-11.

Sultana, H. (2015). Sex worker activism, feminist discourse and HIV in Bangladesh. Culture, health \& sexuality, 17(6), 777-788.

Urmi, A. Z., Leung, D. T., Wilkinson, V., Miah, M. A. A., Rahman, M., \& Azim, T. (2015). Profile of an HIV testing and counseling unit in Bangladesh: majority of new diagnoses among returning migrant workers and spouses. PloS one, 10(10), e0141483.

World Health Organization. (2018). World Health Organization . Retrieved from http://www.searo.who.int/bangladesh/areas/hiv_aids/en/.

Yaya, S., Bishwajit, G., Danhoundo, G., \& Seydou, I. (2016). Extent of knowledge about HIV and its determinants among men in Bangladesh. Frontiers in public health, 4, 246. 